\title{
Culture-dependent characterization of cyanobacterial diversity in the intertidal zones of the Portuguese coast: A polyphasic study
}

Ângela Britoa,b, Vitor Ramosa,b, , Rui Seabrab,c, Arlete Santosa,b, Catarina L. Santosa, Miguel

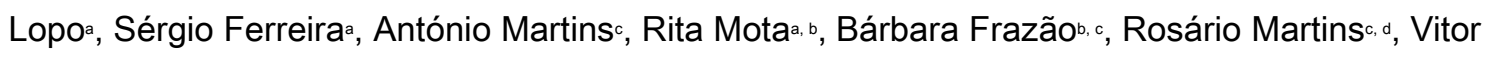
Vasconcelos ${ }^{\mathrm{b}, \mathrm{c}}$, Paula Tamagninia, b,

a IBMC - Instituto de Biologia Molecular e Celular, Universidade do Porto, Rua do Campo Alegre 823, 4150-180 Porto, Portugal

b Faculdade de Ciências, Departamento de Biologia, Universidade do Porto, Rua do Campo Alegre, Edifício FC4, 4169007 Porto, Portugal

c Interdisciplinary Centre of Marine and Environmental Research (CIIMAR/CIMAR), University of Porto, Rua dos Bragas 289, 4050-123 Porto, Portugal

d CISA - Centro de Investigação em Saúde e Ambiente, Escola Superior de Tecnologia da Saúde, Instituto Politécnico do Porto, Rua Valente Perfeito 322, 4400-330 Vila Nova de Gaia, Portugal

\begin{abstract}
Cyanobacteria are important primary producers, and many are able to fix atmospheric nitrogen playing a key role in the marine environment. However, not much is known about the diversity of cyanobacteria in Portuguese marine waters. This paper describes the diversity of 60 strains isolated from benthic habitats in 9 sites (intertidal zones) on the Portuguese South and West coasts. The strains were characterized by a morphological study (light and electron microscopy) and by a molecular characterization (partial 16S rRNA, nifH, nifK, mcyA, mcyEl ndaF, sxt/genes). The morphological analyses revealed 35 morphotypes ( 15 genera and 16 species) belonging to 4 cyanobacterial Orders/Subsections. The dominant groups among the isolates were the Oscillatoriales. There is a broad congruence between morphological and molecular assignments. The 16S rRNA gene sequences of 9 strains have less than $97 \%$ similarity compared to the sequences in the databases, revealing novel cyanobacterial diversity. Phylogenetic analysis, based on partial 16S rRNA gene sequences showed at least 12 clusters. One-third of the isolates are potential $\mathrm{N}_{2}$-fixers, as they exhibit heterocysts or the presence of nif genes was demonstrated by PCR. Additionally, no conventional freshwater toxins genes were detected by PCR screening.
\end{abstract}

\section{Keywords}

Cyanobacteria; Marine; 16S rRNA gene; Nitrogen fixation; Phylogeny; Toxins 


\section{Introduction}

Continental Portugal has an extensive coastline, of about $940 \mathrm{~km}$, facing the North Atlantic Ocean. It is one of the warmest European countries, and its climate is classified as Mediterranean type Csa in the south ( $\mathrm{C}$ - warm temperate; $\mathrm{s}$ - summer dry; $\mathrm{a}$ - hot summer) and $\mathrm{Csb}$ in the north ( $\mathrm{C}$ - warm temperate; s - summer dry; b - warm summer), according to the Köppen's scheme [23]. The near-shore wave energy has a strong spatial and seasonal variability [30]. Western and southern coasts are evidently under different wave regimes, with the unsheltered west coast sites experiencing higher wave height and power than southern ones, and a moderate decreasing gradient from north to south can be observed. Wave height and power in the winter are also much higher than in the summer [30], and along the coast it is possible to encounter different topographies and beach morphologies - rocky beaches, beaches with sand and rocks and sandy beaches with dispersed rocks, resulting in diverse levels of exposure to the prevailing wave regimen.

Cyanobacteria are photosynthetic prokaryotes with a wide geographical distribution that are present in a broad spectrum of environmental conditions [49]. Taxonomy of cyanobacteria is a controversial subject, with two prevailing approaches, the "botanical" and "bacterial". The reorganized taxonomic revision based on the botanical code uses morphological, biochemical and molecular characters [19], [20] and [21]. After the recognition of the prokaryotic features of cyanobacteria, Rippka et al. [36] published a bacteriological taxonomy based on morphological, biochemical and genetic characters of axenic cultures, while Bergey's Manual of Systematic Bacteriology [5] uses a phylogenetic approach primarily based on 16S rRNA sequence comparisons. In summary, cyanobacteria can be classified into five Subsections [5] and [36] that broadly coincide with Orders of the botanical approach [19], [20] and [21]. Cyanobacteria belonging to subsections I (Chroococcales) and II (Pleurocapsales) are unicellular, but while the organisms in subsection I divide exclusively by binary fission, the ones from subsection II can also undergo multiple fission producing small easily dispersible cells called baeocytes. The subsection III (Oscillatoriales) includes the filamentous strains without cell differentiation. Subsections IV (Nostocales) and V (Stigonematales) comprise the filamentous strains that are able to differentiate heterocysts and akinetes. In addition, filaments of cyanobacteria from subsection $\mathrm{V}$ are able to divide in multiple planes displaying true branching.

Benthic cyanobacteria grow along the shore on different substrata, mainly in the intertidal zones, as part of complex multi-taxa communities, often forming cohesive mats and biofilms. In these habitats, they are exposed to a range of daily stresses such as nutrient limitation, high UVradiation and desiccation[1] and [6]. The successful adaptation to these harsh environments is largely due to their morphological and functional versatility [31]. Cyanobacteria play a major role in the global carbon cycle as important primary producers performing oxygenic photosynthesis, and the diazotrophic taxa are fundamental to the nitrogen cycle, particularly in oceans [18]. In addition to their ecological importance, cyanobacteria are also recognized as being a prolific source of biologically active natural products; some of these compounds are toxic to a wide array 
of organisms [50]. Nevertheless, little is known about the diversity of these organisms along the Portuguese coast with only a few reports published [2] and [9]. Araújo et al. [2] provided an updated checklist of the benthic marine algae of the northern Portuguese coast, including 26 species of cyanobacteria. However, these authors based their work on new records, literature references and herbarium data but did not isolate or maintain cultures of the observed specimens. The aim of this work was to identify the cyanobacteria present in the intertidal zones of the Portuguese coast using a polyphasic approach. The isolated specimens are kept at LEGE Culture Collection, and available for further studies. In addition to the assessment of cyanobacterial diversity, a PCR-based screen for putative diazotrophs and toxin-producers was performed to unveil their role(s) in the ecosystem.

\section{Materials and methods}

\section{Sampling sites}

The sites (Table 1) were selected in order to represent the diversity of the Portuguese coast. Along the coast it is possible to discriminate between rocky beaches (sampling sites 1 and 8), beaches with sand and rocks (sampling sites 2, 3, 4, 7) and sandy beaches with dispersed rocks (sampling sites 5, 6 and 9) (Table 1). Several relevant variables: wave power [30], sea surface temperature [SST [25]], river runoff and other important climatic variables such as air temperature and precipitation (Instituto de Meteorologia, IP, Portugal) were also taken into account. In brief, West coast sampling sites experience generally higher energetic wave regimes, lower overall mean SSTs and mean air temperatures [40], and higher fresh water inputs, both from river runoff and precipitation, than their South coast counterparts.

Table 1
Localization and characteristics of the sampling sites.

\section{Cyanobacteria sampling, isolation, and culturing}

Biological samples were collected in both summer and autumn of 2006, and spring of 2007. Sample collection was performed by scraping the surface of a wide range of substrates (e.g. seaweeds, rock surfaces, seashells, Sabellaria alveolata reefs) present on bare rocks or shallow 
puddles tidal pools. For the isolate LEGE 06009 see also [9]. In addition, seawater samples from the surf zone were also collected.

Raw biological samples were screened for cyanobacterial specimens using a light microscope (Leica DMLB), and subsequently subjected to liquid culture enrichment, agar plates streaking or micromanipulation. Whenever possible single cells/filaments were isolated and transferred to liquid or solid medium using a Pasteur pipette [34]. When micromanipulation was found unsuitable, aliquots of the enriched liquid cultures were transferred to liquid medium or streaked on agar plates. Sea water samples were filtered with sterile glass fiber filters (GF/C - $\varnothing 47 \mathrm{~mm}$, Whatman), and subsequently placed on liquid medium until a visible colony appeared. Single colonies were picked and streaked on agar plates. New colonies were transferred into liquid medium. Cultures were maintained using the following media: MN [34], BG110, BG11 [44], and Z8 [22] supplemented with $25 \mathrm{~g} \mathrm{~L}^{-1} \mathrm{NaCl}$, further named Z8 25\%. The media were supplemented with B12 vitamin, and when necessary with cycloheximide or amphothericin B [34]. The cultures were kept under $14 \mathrm{~h}$ light $\left(10-30 \mu \mathrm{mol}\right.$ photons $\left.\mathrm{m}^{-2} \mathrm{~s}^{-1}\right) / 10 \mathrm{~h}$ dark cycles at $25^{\circ} \mathrm{C}$. Cyanobacterial isolates are deposited at LEGE Culture Collection (Laboratório de Ecotoxicologia, Genómica e Evolução; CIIMAR, Porto, Portugal). Additionally, the isolate LEGE 06123 is also deposited at Culture Collection of Algae and Protozoa (CCAP 1425/1), for details on this organism see [33].

\section{Light and transmission electron microscopy (TEM) and morphological identification}

Cells were observed using a Leica DMLB microscope (Leica Microsystems $\mathrm{GmbH}$ ), images were captured with a Leica ICCA Analogue Camera System, and the cells were measured using Qwin Leica software (Leica Microsystems $\mathrm{GmbH}$ ). Each morphometric parameter was measured 20 times in different individuals.

For TEM studies, cells were collected, centrifuged and processed as described by Seabra et al. [39]. Sections were examined using a Zeiss EM 902.

The morphological identification was carried out following the criteria of Komárek and Anagnostidis [19],[20] and [21], Waterbury and Stanier [47] and by using Bergey's Manual of Systematic Bacteriology [4], i.e. whenever the identification differs in the two systems ("botanical " and "bacteriological"), the corresponding form-genus in Bergey's classification is also mentioned. For Pleurocapsales Waterbury and Stanier [47]classification was followed.

\section{DNA extraction, purification, PCRs and sequencing}

Cells were harvested by centrifugation and DNA was extracted using the Maxwe $\| 16$ System, and the Cell DNA Purification Kit for Gram-negative bacteria (Promega Corporation) according to the instructions of the manufacturer. DNA fragments within the following genes were amplified using the oligonucleotide primers listed on Table 2: 16S rRNA gene (small subunit ribosomal gene), nifK(dinitrogenase $\beta$ subunit), nifH(dinitrogenase reductase), mcy $A$ and $m c y E$ (microcystin 
synthetase), $n d a F$ (nodularin synthetase), andsxt/ (saxitoxin biosynthesis). The $16 \mathrm{~S}$ rRNA gene was amplified using two primer pairs, each including one universal primer and one specific for cyanobacteria [8-27F(universal)/CYA781R(specific), and CYA361F(specific)/1492R(universal)], this allowed us to amplify a longer fragment, and to avoid unspecific amplifications since the cultures are not axenic. For nifK, the first group of primer pairs (see Table 2) was designed for filamentous cyanobacteria, whereas the second group was designed for unicellular cyanobacteria. PCR reactions were performed using a thermal cycler MyCyclerTM (Bio-Rad laboratories Inc., Hercules, CA, USA) following [45]. The PCR profiles, after a $2-5$ min at $94{ }^{\circ} \mathrm{C}$ of denaturation step, were the following: $16 \mathrm{~S}$ rRNA gene -35 cycles of $94^{\circ} \mathrm{C} 1 \mathrm{~min}, 50^{\circ} \mathrm{C} 1 \mathrm{~min}$, and $72{ }^{\circ} \mathrm{C} 1 \mathrm{~min} 30 \mathrm{~s}$; nifK -30 cycles of $94^{\circ} \mathrm{C} 1 \mathrm{~min}, 50^{\circ} \mathrm{C} 1 \mathrm{~min}$, and $72{ }^{\circ} \mathrm{C}$ for $1 \mathrm{~min} 15 \mathrm{~s} ; m c y A$, $m c y E$, and $n d a F-30$ cycles of $95^{\circ} \mathrm{C} 1 \mathrm{~min} 30 \mathrm{~s}, 52^{\circ} \mathrm{C} 30 \mathrm{~s}$, and $72{ }^{\circ} \mathrm{C} 50 \mathrm{~s}$; sxtl- 30 cycles of $94^{\circ} \mathrm{C} 10 \mathrm{~s}, 52{ }^{\circ} \mathrm{C} 20 \mathrm{~s}$, and $72{ }^{\circ} \mathrm{C} 1 \mathrm{~min}$. In all cases a final extension of $7 \mathrm{~min}$ at $72{ }^{\circ} \mathrm{C}$ was performed. Amplification of the nifH fragment was performed according to the methods described previously [29]. The PCR products were separated by agarose gel electrophoresis using standard protocols [38]. DNA fragments were isolated from gels using the NZYGelpure Kit (NZYtech, Lda. INOVISA, Lisbon, Portugal), according to the manufacturer's instructions. Purified PCR products were cloned into pGEM ${ }^{\oplus-T}$ Easy vector (Promega, Madison, WI, USA), and transformed into Escherichia coli DH5a competent cells following the manufacturer's instructions, and the methodology described in [33]. Some purified PCR products were directly sequenced at STAB Vida (Lisbon, Portugal).

\begin{tabular}{|c|c|c|c|c|}
\hline Target genes & Primer pair ${ }^{a}$ & Sequence $5^{\prime} \rightarrow 3^{\prime}$ & PCR product expected size (bp) & Reference \\
\hline \multirow[t]{5}{*}{$16 \mathrm{~S}$ rRNA } & $8-27 \mathrm{~F}$ & AGAGTTTGATCCTGGCTCAG & & [48] \\
\hline & CYA781R (A) ${ }^{\mathrm{b}}$ & GACTACTGGGGTATCTAATCCCATT & 773 & [28] \\
\hline & CYA781R (B) & GACTACAGGGGTATCTAATCCCTTT & & [28] \\
\hline & CYA361F & GGAATTTTCCGCAATGGG & 1131 & [27] \\
\hline & $1492 \mathrm{R}$ & GGTTACCTTGTTACGACTT & & [48] \\
\hline \multirow[t]{10}{*}{ nifK } & nifKOF (A) & CAAGGTTCTCAAGGTTGCGTT & 1139 & [33] \\
\hline & nifK1F (B) & CAAGGTTCTCAAGGTTGTGTG & & [33] \\
\hline & nifK4R & TGTAAGTGGTGGCGATCAAAGA & & [33] \\
\hline & nifKOF (A)/nifK1F (B) & See above & 407 & [33] \\
\hline & nifK3'R $R$ & GGGATGAAGTTGATTTTGCCGTT & & This work \\
\hline & nifk146F & CCTGGGAATATCGGGAA & 319 & This work \\
\hline & nifk465R & GCCATACAAGTTGTACAGACA & & This work \\
\hline & nifk310F & CGTCACTTCAAAGAGCCTT & 1084 & This work \\
\hline & nifk1394R & GGCGATCAAAGATAGGATA & & This work \\
\hline & nifH4 & TTYTAYGGNAARGGNGG & & [29] \\
\hline \multirow[t]{3}{*}{ nifH } & nifH3 & ATRTTRTTNGCNGCRTA & 361 & [29] \\
\hline & nifH2 & ADNGCCATCATYTCNCC & & [29] \\
\hline & nifH1 & TGYGAYCCNAARGCNGA & & [29] \\
\hline \multirow[t]{2}{*}{ mсуA } & mсуA-Cd1F & AAAAGTGTTTTATTAGCGGCTCAT & 297 & [14] \\
\hline & mсуA-Cd1R & AAAATTAAAAGCCGTATCAAA & & [14] \\
\hline \multirow[t]{2}{*}{ mcyE/ndaF } & HEPF & TTTGGGGTTAACTTTTTTGGGCATAGTC & 472 & [16] \\
\hline & HEPR & AATTCTTGAGGCTGTAAATCGGTTT & & [16] \\
\hline \multirow[t]{2}{*}{ sxtI } & sxtl-F2 & GGATCTCAAAGAAGATGGCA & 991 & This work \\
\hline & sxtl-R & GGTTCGCCGCGGACATTAAA & & {$[17]$} \\
\hline
\end{tabular}

b (A) and (B) - primers used together in a mixture with equimolar concentration.

\section{Nucleotide sequence accession numbers}

Novel sequences associated with this study are available in GenBank under the accession numbers FJ589716, HQ832895-HQ832951, JF708120 and JF708121. 


\section{Phylogenetic analysis}

In order to integrate the cyanobacterial diversity along the Portuguese coast into a broader phylogenetic context, the 16S rRNA gene sequences were analyzed, compared with the currently available databases and used to construct phylogenetic trees. Each sequence was independently used as the query in a BLAST search against the non-redundant nucleotide database of the National Centre for Biotechnology Information (NCBI, March 2011). In order to include full-length sequences and to obtain a reliable overall picture of the cyanobacterial diversity, a number of reference strains from each subsections/orders represented in our samples were retrieved from GenBank and were included in the following phylogenetic analyses. The reference strains were selected according to the Bergey's Manual of Systematic Bacteriology (2001), and from those the ones closely related to our samples were used. A multiple alignment encompassing $16 S$ rRNA gene sequences from the isolates, the reference strains and Chloroflexus aurantiacus $\mathrm{J}-10-\mathrm{fl}$ as the outgroup was performed using the ClustalW2 algorithm [24], with all the default parameters. Due to the size differences in the amplification products of each isolate, and to avoid the consequent bias effect on the tree construction, this alignment was pruned to an internal core of 655 nucleotides present in all sequences - corresponding to nucleotides 519 to 1172 in E. coli. The phylogenetic tree was computed using the Maximum-likelihood (ML) methodology [8]. The alignment was imported to Geneious Pro [7], and the tree was build with the PhyML [12] plugin, using the HKY85 as the substitution model and 1000 pseudo-replicates for the bootstrap analysis, and allowing the software to estimate the transition/transversion ratio, the proportion of invariable sites and the gamma distribution parameter with 4 substitution rate categories.

\section{Results and discussion}

This work presents a polyphasic study of cyanobacterial isolates from selected intertidal zones along the Portuguese coast, combining the isolation of strains, and their characterization by microscopic observations and molecular analysis.

\section{Morphological characterization}

To evaluate the diversity of cyanobacteria, nine beaches that reflect the heterogeneity of habitats present along the continental Portuguese coast were selected (Table 1). Approximately 100 cyanobacterial isolates were retrieved, from which 60 were characterized and shown to belong to 35 different morphotypes. Fifteen genera and 16 species belonging to four cyanobacterial orders/subsections were identified based on morphological characters (Table S1, supplementary material). In terms of the isolate's spatial distribution no clear pattern was observed, i.e. the different cyanobacterial groups are distributed by all the different beaches types. However, one must take into account that the number of isolates of certain genera is much higher than others, and that the different number of isolates obtain for each genus can be due to their ubiquity or to the fact that they are easier to isolate. The isolation media were selected due to their different composition in order to expose the highest possible diversity. MN medium revealed the highest 
diversity, Z8 25\% was particularly successful for coccoids and Leptolyngbya spp., while BG11 and BG11 did not contribute to a higher diversity than the Z8 25\%, with the exception of Nostoc sp. LEGE 06158. The most representative group among the isolates comprises the nonheterocystous forms, notably the filamentous Oscillatoriales and the unicellular Chroococcales. Representatives from the unicellular Pleurocapsales were also found, as well as heterocystous taxa: Nostocales ( Fig. 1). No true-branching filamentous, Stigonematales, were found. The nonheterocystous cyanobacteria are, indeed, reported as the predominant forms in marine environments [3], [6], [43] and [46]. This seems to be also the case for Portugal, the Checklist of benthic marine algae and cyanobacteria of northern Portugal ("Checklist") reported 26 species of cyanobacteria, 15 of which are Oscillatoriales [2]. Strains belonging to the generaHyella, Myxosarcina, Lyngbya, Pseudophormidium and Calothrix were found in the same area (north of Portugal) as reported in the Checklist. Cyanobium, Leptolyngbya and Pseudanabaena are the most numerous among our isolates ( Table S1 and Table 3). Some genera described by [2] were not found in our study (Chamaecalyx, Dermocarpella, Entophysalis, Hydrococcus, Trichocoleus, Porphyrosiphon, Siroc oleum, and Spirocoleus), whereas Xenococcus, Microcoleus, Spirulina morphotypes were present in our field samples but its isolation was not successful. On the other hand, genera that are not described by these authors were present in our samples (Aphanothece, Cyanobium, Synechocystis, Chroococcidiopsis, Chroococcopsis, Leptolyngbya, Pseudanabaena, Romeria, Schizothrix, Nostoc, and Scytonema), some of them also confirmed by a recent studies on the Portuguese coast: Synechocystis, Cyanobium, and Leptolyngbya [9] and [26]. However, Araújo et al. [2] based their work not only on new records but also on literature references and herbarium data, and did not isolate the observed specimens. Representatives of the order Stigonematales were not found in this study nor reported by Araújo et al. [2]. This was expected since it is known that these organisms are poorly represented in marine environments [15], and mainly encountered in the flowing waters of hot springs and soils [11], [36] and [52]. 


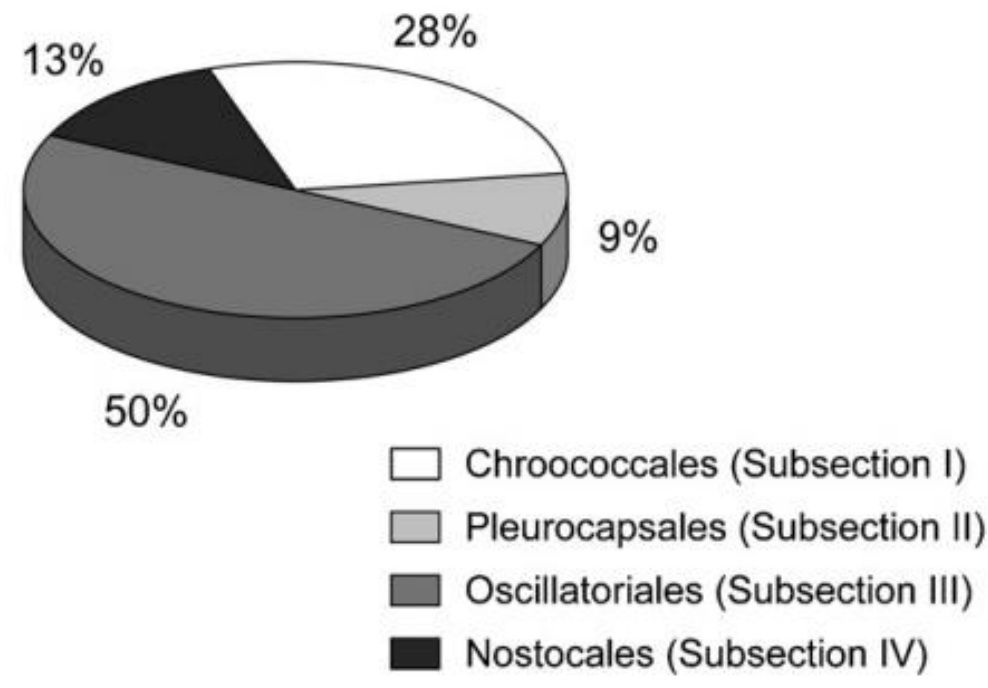

Fig. 1. Distribution of the isolates per taxonomic group. 
Table 3

Morphological identification (for details see Table S1) and molecular analysis of the cyanobacterial isolates.

\begin{tabular}{|c|c|c|c|c|c|c|c|}
\hline $\begin{array}{l}\text { ORDER (Subsection) } \\
\text { Genus and species }\end{array}$ & $\begin{array}{l}\text { LEGE } \\
\text { code }\end{array}$ & Site $^{a}$ & $\begin{array}{c}\text { Accession } \\
\text { number }\end{array}$ & $\begin{array}{l}\text { Best hit indicated by BLAST } \\
\text { 16S rRNA gene }\end{array}$ & $\begin{array}{c}\% \\
\text { Max. } \\
\text { Identity }\end{array}$ & Closest known relative & $\begin{array}{c}\% \\
\text { Max. } \\
\text { Identity }\end{array}$ \\
\hline \multicolumn{8}{|l|}{ CHROOCOCCALES (I) } \\
\hline Aphanothece of. salina (Symechococcus) & 96149 & 1 & HQ832898 & Symechococcus sp. G2.1 (AY054298) & 99 & & \\
\hline Cyamotium sp. & 06137 & 3 & HQ832914 & Cyamobium sp. NSOL (AY172837) & 100 & & \\
\hline Cyamobium sp. & 06109 & 4 & но832920 & Cyamobium sp. NSOL (AY172837) & 100 & & \\
\hline Cyanobium sp. & $961+0$ & 4 & Hе832922 & Cyamobium sp. NSO1 (AY172837) & 100 & & \\
\hline Cuamobium sp & 06012 & 5 & HO832926 & Cyamobium sp. NSO1 (AY172837) & 99 & & \\
\hline Cyanobium sp & 96097 & 6 & HQ832928 & Cyamobium sp. NS01 (AY172837) & 100 & & \\
\hline Cyamobium sp. & 07153 & 6 & HQ832931 & Symechococcus sp. HOS (AF448064) & 98 & & \\
\hline Cyamobium sp. & 06127 & 7 & HQ832935 & Cyanobium sp. NSO1 (AY172837) & 100 & & \\
\hline Cyamotium sp. & ${ }^{06143}$ & 7 & HQ832936 & Cyanobium sp. NSO1 (AY172837) & 100 & & \\
\hline Cyanobium sp. & 96184 & 7 & HQ832940 & Symechococeus sp. PS838 (AF448068) & 99 & & \\
\hline Cyamobium sp: & 96130 & 9 & Hе832946 & Cyamobiam sp. NSOI (AY172837) & 99 & & \\
\hline Glowocapsopsis ef. crepidinum & 06123 & 8 & FJ589716 & $\begin{array}{l}\text { Unicellular thermophilic cyanobacterium }{ }_{2} \mathrm{BTRCCn} \\
23 \text { (DQ471449) }\end{array}$ & 97 & Pleurocapsa ef. concharum 1d-08 (FR798928) & 94 \\
\hline Symechococcus midulans & 07171 & 7 & HQ832939 & $\begin{array}{l}\text { Uncultured eyanobacterium clone SPI_ IB } 30 \\
(60225753\end{array}$ & 97 & Aphamocapsa muscicola 5N-04 (FR798920) & 95 \\
\hline Simechoroccus sp. & 07172 & 9 & Hе832950 & Simedhococecus sp. MBIC10613 (AB183569) & 99 & & \\
\hline Symechocystis salina & 06099 & 1 & HQ832895 & Symechogustis sp. PCC 6803 (BA000022) & 99 & & \\
\hline Smechorystis salina & 96155 & 2 & HQ832911 & Symechogastis sp. LMECYA 68 (EU078508) & 99 & & \\
\hline Symechocystis salina & 07173 & 9 & Hе832951 & Cyamobium sp. NSOl (AY172837) & 99 & & \\
\hline \multicolumn{8}{|l|}{ PLEUROCAPSALES (II) } \\
\hline Chroococcidiopsis sp. & 96174 & 4 & HQ832924 & Pleurocapsa sp. CALU 1126 (DQ293994) & 99 & & \\
\hline $\begin{array}{l}\text { Chrooccoccopsis sp. (Myxosarcina \& Pleurocapsa- } \\
\text { group) }\end{array}$ & 07187 & 1 & HQ832904 & Myxosarcina sp. PCC 7325 (AJ344562) & 99 & & \\
\hline 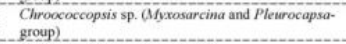 & 07161 & 6 & HQ832932 & $\begin{array}{l}\text { Uncultured eyanobacterium clonc } \mathrm{AO} 26 \\
(\mathrm{~F} 3589912)\end{array}$ & 96 & $\begin{array}{l}\text { Cyamobacterium sp. MBIC10216 } \\
\text { (AB058249) }\end{array}$ & 94 \\
\hline Hyella sp (Plearocapsa-group) & 07179 & 1 & HO832901 & Chroococcidiopsis sp. PCC 6712 (AJ344557) & 95 & & \\
\hline $\begin{array}{l}\text { Myxasarcina sp. (Chroococcidiopsis) } \\
\text { OSCILLATORIALES (III) }\end{array}$ & & \\
\hline Leptolyng bya ef. halophila & 06110 & 1 & HQ832896 & Leptolmybbya sp. 0BB19S12 (AJ639895) & 99 & & \\
\hline Leptobungbva ef halophila & 06102 & 2 & HQ832906 & Leprobugbbsa nodulasa UTEX 2910 (EF 122600 ) & 99 & & \\
\hline Leptolyng bya ef. halophila & 96152 & 3 & HQ832915 & $\begin{array}{l}\text { Uneultured bacterium clone ned } 516 \mathrm{~h} 07 \mathrm{cl} \\
\text { (JF } 046736)\end{array}$ & 98 & $\begin{array}{l}\text { Leptolyngbya nodulasa UTEX } 2910 \\
\text { (EF 122600) }\end{array}$ & 98 \\
\hline Leptolyngbva fragilis & 07167 & 3 & HQ832917 & $\begin{array}{l}\text { Uncultured cyanobacterium clone SC3-19 } \\
\text { (DQ289927) }\end{array}$ & 94 & Cyanothece sp. PCC 8802 (CP001701) & 93 \\
\hline Leptolyngbya fragilis & 07176 & 4 & HO832925 & Glocothece sp. KOIIDG (AB067577) & 94 & & \\
\hline Leptolyngbya minuta & 07181 & 1 & HQ832903 & Phormidium sp. MBIC10070 (AB058219) & 99 & & \\
\hline Leptolyng gbya mycoidea & 07157. & 3 & HOQ832916 & Uncultured bacterium clone CIScm 45 (EF 208676 & 93 & Cranothece sp. PCC 8802 (CP001701) & 93 \\
\hline Leptobingbsa mucoudea & 06009 & 5 & JF708121 & Leptolymgbra nodulosa UTEX 2910 (EF 1226000 & 98 & & \\
\hline Leptobingbya mycoridea & 06126 & 7 & HQ832934 & $\begin{array}{l}\text { Psendanabaemaceae cyanobacterium DPG1-KK5 } \\
\text { (F655067 }\end{array}$ & 99 & Leptolyngbia sp. 0BB24S04 (AJ639893) & 99 \\
\hline Leptolongbrya mucerded & 06108 & 8 & но832942 & Leptolomgrbsusp. PCC 9221 (AF317507) & 100 & & \\
\hline Leptolyngbya mucoided & 06118 & 8 & HQ832943 & Leptobumgbya sp. PCC 9221 (AF317507) & 100 & & \\
\hline Leptolongbya saricola & 07132 & 8 & HQ832944 & Leppolymgbya sp. ITAC101 (GU220365) & 100 & & \\
\hline Leptobmgbras saxicola & 07170 & 9 & HQ832949 & Uncultured bacterium clone Mfra_ HII (GUI 18858) & 98 & $\begin{array}{l}\text { Leptolyngbya antarctica ANT.FIRELIGHT.1 } \\
\text { (AY493590) }\end{array}$ & 95 \\
\hline Leptotyng bya sp. 1 & 06121 & 9 & HO832945 & Leptobmgbya sp. 0BB24S04 (A)639893) & 98 & & \\
\hline Leppolyngbya sp. 2 & 06188 & 3 & HQ832918 & $\begin{array}{l}\text { Uncultured cyanobacterium clone VERDEA } 95 \\
\text { (F)902665) }\end{array}$ & 95 & Leptolyngbya sp. 1T12e (FR798935) & 94 \\
\hline Lawgbba cf. aestharil & 07165 & 2 & HQ832912 & 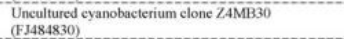 & 98 & Lumgbya majuscula CCAP 14464 (HO419207) & 95 \\
\hline Phormidium laetevirens (Oscillatoria) & 06103 & 8 & JF708120 & $\begin{array}{l}\text { Uncultured cyanobacterium, clone } 27 \mathrm{~T} 9 \mathrm{~d}-\mathrm{oil} \\
\text { (FM242382) }\end{array}$ & 95 & 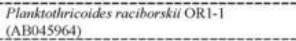 & 95 \\
\hline Phormidium sp 1 (Leptolyngbya) & 06111 & 6 & $\mathrm{HQ832929}$ & Uncultured bacterium clone SHFH692(F 203604 ) & 95 & Cyanothece sp. PCC 8802 (CP001701) & 94 \\
\hline Phormidium sp. 2 (Oscillatoria) & 07162 & 1 & HO832899 & Uneultured bacterium clone C15em 45 (EF208676) & 93 & Stanieria cyunasphaera PCC 7437 (AF132931) & 92 \\
\hline Plectonema ef radiosum (Scytonema) & 06105 & 8 & $\mathrm{HQ} 832941$ & Calothirix sp. CCMEE 5085 (AY147030) & 99 & & \\
\hline Psendanabaena aff. curta & 07169 & 4 & Hо832923 & $\begin{array}{l}\text { Uncultured cyanobacterium, clone UMAB-cl-31 } \\
\text { (fN81215) }\end{array}$ & 97 & Symechocarcus sp. PCC 7335 (AB015062) & 96 \\
\hline Psendanabaena aff. curta & 07160 & 9 & HQ832948 & Symechococecus sp. PCC 7335 (AB015062) & 98 & & \\
\hline Psendmabaena aff. persicina & 07163 & 1 & HQ832900 & $\begin{array}{l}\text { Pserudophormidium sp. ANT PENDANT.3 } \\
\text { (YY499387) }\end{array}$ & 97 & & \\
\hline Pseudanabaena ef frigida & $061+4$ & 7 & но832937 & Leptolyngbya sp. FLKBBDI (EF110975) & 98 & & \\
\hline Pseudanabaena sp. 2 & 06129 & 4 & HQ832921 & Oseillatoriales cyanobacterium 2Dp86E (GU265558) & 98 & Leptolyngbya sp. 0BB24S04 (AJ639893) & 98 \\
\hline Psendanabaena sp. 3 & 07190 & 3 & HQ832919 & $\begin{array}{l}\text { Uncultured cyanobacterium clone R8-B31 } \\
\text { (DQ181689 }\end{array}$ & 98 & $\begin{array}{l}\text { Phormidium pristleyi ANT.ACEV5.1 } \\
\text { (AY493586) }\end{array}$ & 97 \\
\hline Psendanabaena sp. 3 & 06116 & 6 & но832930 & LPP-group MBIC10086 (AB058224) & 98 & Langbya sp. A09DM (HM446280) & 97 \\
\hline Pseudophormidium sp. & 061 & 2 & HQ832909 & Leptolyngbya foveolarum PMC302.07 (G0859653) & 99 & & \\
\hline Romeria sp. (Pseudanabaena $)$ & 96013 & 5 & HQ832927 & ccus sp. G2.1 (AY054298) & 99 & & \\
\hline Schizothrix aff. septentrionalis & 07164 & 1 & HQ832902 & $\begin{array}{l}\text { Uncultured cyanobacterium clone DPC044 } \\
\text { (DO269094) }\end{array}$ & 98 & Leptolyngbya sp. FL.KBBDI*(EF110975) & 92 \\
\hline \multicolumn{8}{|l|}{ NOSTOCALES (IV) } \\
\hline Calothrix sp. 1 (Rivularia) & 06100 & 3 & HQ832913 & Uncultured bacterium clone GBII-17 (GQ441291) & 98 & Rivularia atra BIR KRIVI (AM230674) & 97 \\
\hline Caloditirix sp. 2 (Rivularia) & 06122 & 2 & HQ832908 & Uncultured bacterium clone $\mathrm{GBl}-7$ (GQ441198) & 99 & Calothrix sp. XP9A (AM230670) & 97 \\
\hline Calothrix sp. 2 (Rivalaria) & 07177 & 6 & HQ832933 & Uncultured bacterium clone GBI-7 (GQ441198) & 99 & Calothrix sp. XP9A (AM230670) & 97 \\
\hline Nosstoe sp. I & & 2 & & Nostoc sp. 1189P (GU062468) & 98 & & \\
\hline Nostoc sp. 1 & & 2 & HQ832910 & Nastox sp. 1189P (GU062468) & 98 & & \\
\hline Nostoe sp. 2 & 06158 & 9 & HQ832947 & Nastroc sp. 'Collema crispum cyanobiont' (DO185216) & 99 & & \\
\hline Rivularia sp. & 07159 & 7 & HQ832938 & Uncultured bacterium elone GBI-7 (GQ441198) & 98 & Calothrix sp. PCC 7507 (AM230678) & 97 \\
\hline Scytonema sp. & 07189 & 1 & HQ832905 & Uncultured bacterium clone GBI-7 (GQ441198) & 98 & Calothrix sp. XP9A (AM230670) & 98 \\
\hline
\end{tabular}

"1- Moledo do Minho, 2- S. Bartolomeu do Mar, 3- Lavadores, 4- Aguda, 5- Foz do Arelho, 6- Martinhal, 7- Burgau, 8- Luz, 9- Olhos d'Água; for details see Table 1.

The diversity of our cyanobacterial isolates is depicted in Fig. 2 and Fig. 3 (as well as in Figs.

S1 and S2), where it is possible to observe genera belonging to the four orders. The

Chroococcales Synechocystis and Cyanobium dividing in one plane ( Fig. 2a and b, Fig. 3a and

b), the Pleurocapsales Chroococcopsis, Myxosarcina and Hyella dividing in more than one plane

( Fig. 2c-g, Fig. 3d) and producing baeocytes ( Fig. 2f), the

Oscillatoriales Romeria, Phormidium, Leptolyngbya, Pseudophormidium, Lyngbya andPlectone

ma ( Fig. 2h-q, Fig. 3e-f), with Leptolyngbya cf. halophila exhibiting nodule-like structures ( Fig. 
2m, Fig. 3f) and Plectonema cf. radiosum geminate false branches ( Fig. 2q), and the Nostocales generaNostoc, Calothrix and Scytonema ( Fig. 2r-u, Fig. 3g), with intercalar ( Fig. 2t) or terminal ( Fig. 2s) heterocysts. In Calothrix sp. LEGE 06100 hormogonia were found ( Fig. $2 u$ ). Additionally, the ultrastructural images provided information on the size and shape of the sheath ( Fig. 3e, f and i), and the different arrangement of the thylakoids ( Fig. 3a-c, e, g and h). It was also possible to observe the disruption of the mother sheath leading to disintegration of the colonies after cell division ( Fig. 3c), and a nodule detail of Leptolyngbya cf. halophila LEGE 06102 ( Fig. 3f). A brief description of each of the isolates and the morphological characteristics used to taxonomically affiliate them is depicted in Table S1, as well as their distribution and habitat description. 


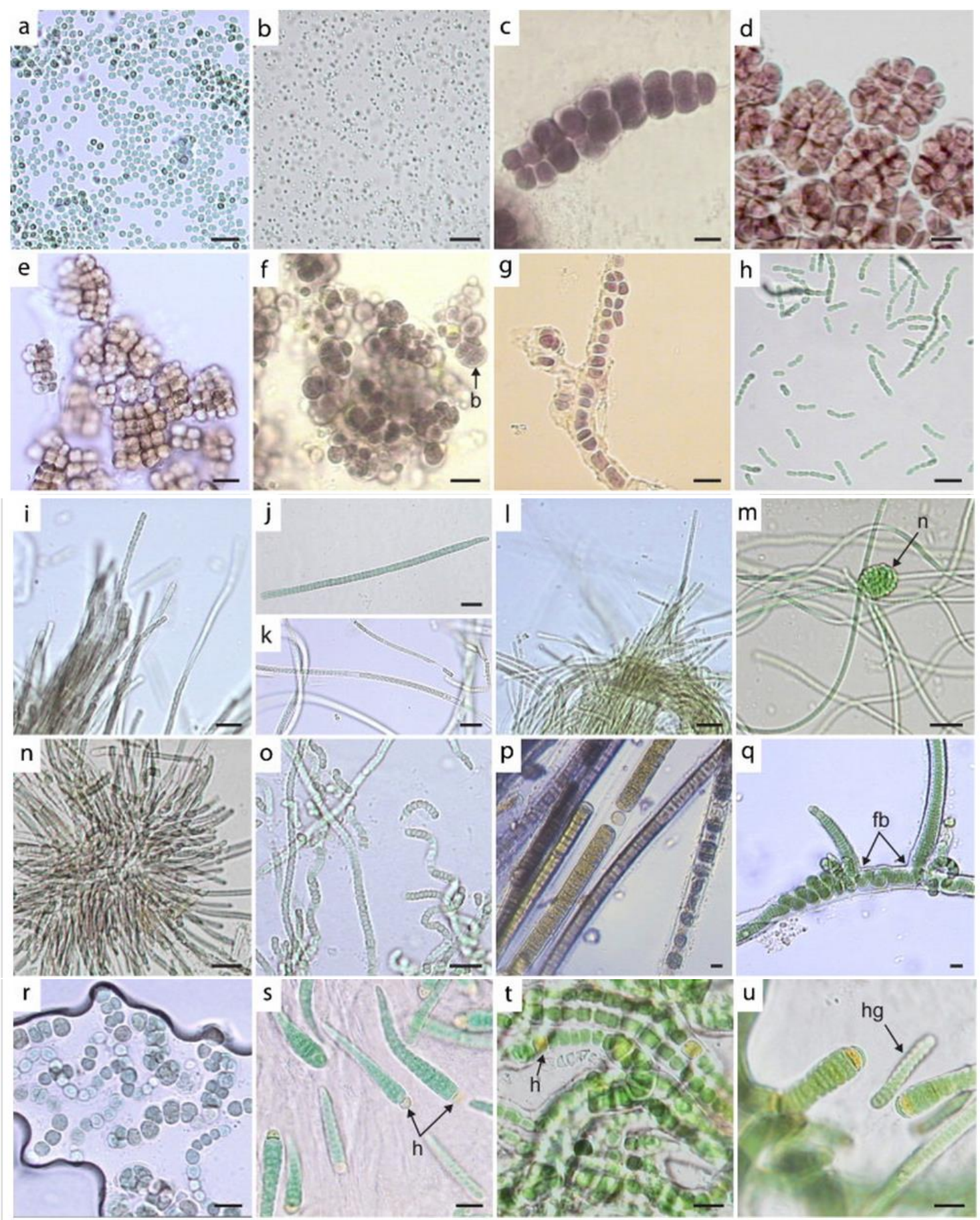

Fig. 2.

Light micrographs illustrating the diversity of cyanobacterial morphotypes isolated from the intertidal zones of nine beaches on the Portuguese coast. (a) Synechocystis salina LEGE 06099, (b) Cyanobium sp. LEGE 06184, (c) Chroococcopsis sp. LEGE 07168, (d) Chroococcopsissp. LEGE 07187, (e) Myxosarcina sp. LEGE 06146, (f) Chroococcopsis sp. LEGE 07161, (g) Hyella sp. LEGE 07179, (h) Romeriasp. LEGE 06013, (i) Phormidiumsp. 1 LEGE 06111, (j) Phormidium laetevirens LEGE 06103, (k) Leptolyngbya mycoidea LEGE 06126, (I) Leptolyngbya mycoidea LEGE 06118, (m) Leptolyngbya cf. halophila LEGE 06102, (n) Leptolyngbya sp. LEGE 06188, (o) Pseudophormidium sp. LEGE 06125, (p) Lyngbya cf. aestuarii LEGE 07165, (q) Plectonema cf. radiosum LEGE 06105, (r) Nostocsp. 1 LEGE 06106, (s) Calothrix sp. LEGE 06122, (t) Scytonema sp. LEGE 07189, (u) Calothrix sp. LEGE 06100. $b$ - baeocytes; fb-false branching; hg - hormogonia; $h$ - heterocysts; $n$ - nodule. Scale bars $-10 \mu m$. 


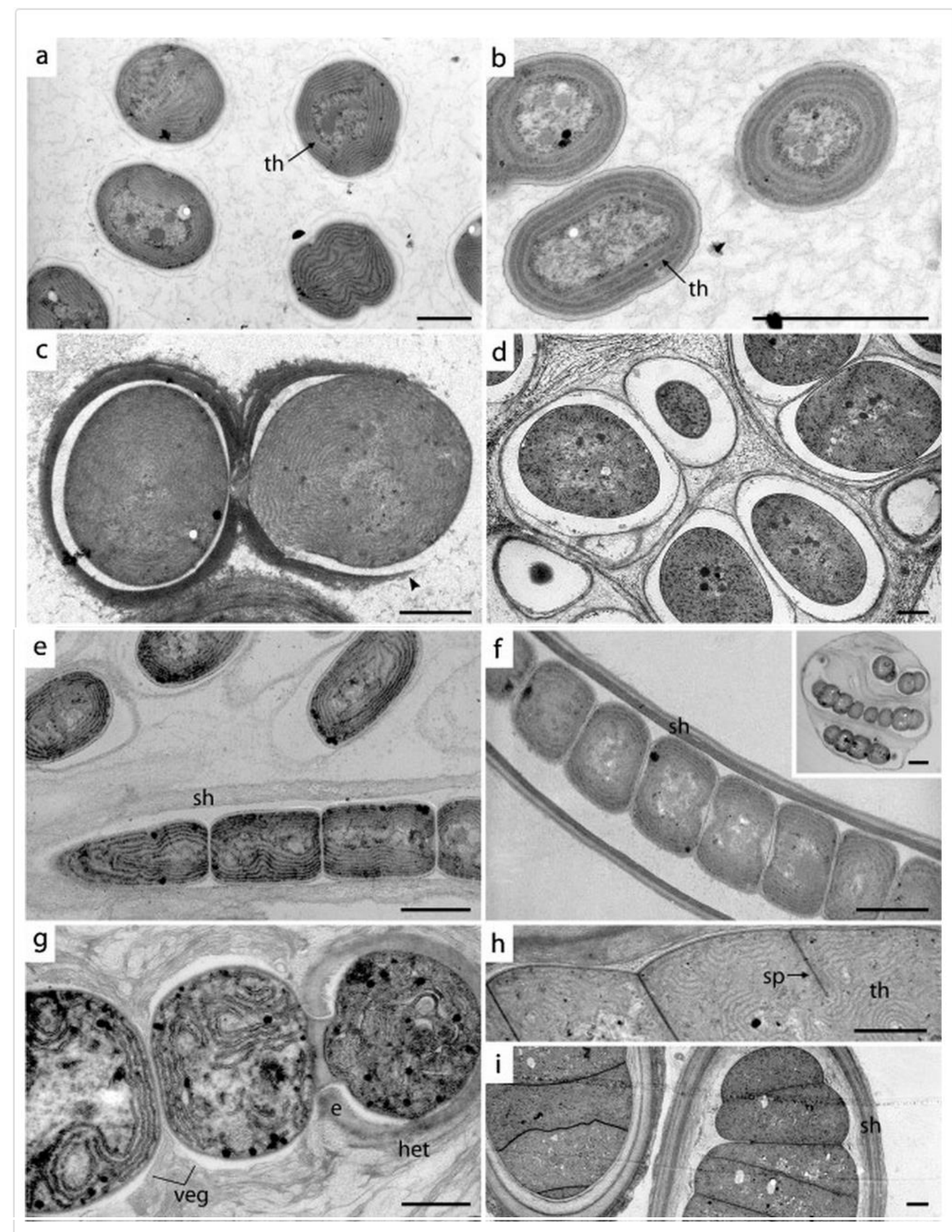

Fig. 3.

Transmission electron micrographs of selected isolates from the sampling sites. (a) Synechocystis salina LEGE 06099, (b) Cyanobium sp. LEGE 06097, (c) Gloeocapsopsis cf. crepidinum LEGE 06123, (d) Chroococcopsis sp. LEGE 07187, (e) Leptolyngbya mycoidea LEGE 06118, (f) Leptolyngbya cf. halophila LEGE 06102, insert - nodule detail (g) Nostoc sp. 2 LEGE 06158, (h) Calothrixsp. 2 LEGE 06122, (i) Rivularia sp. LEGE 07159. het - heterocyst; sh - sheath; sp-septum; th - thylakoid; veg - vegetative cell. arrow head - disruption of the mother sheath. Scale bars $-1 \mu \mathrm{m}$. 


\section{DNA sequence and phylogenetic analysis}

Partial 16S rRNA gene sequences were obtained for all the isolates. These sequences were compared with the ones available in the NCBI database (March 2011) using BLASTn, and the results are shown inTable 3 . There was a quite good correlation between the phenotypic and genotypic based identifications, for more than one-third of the isolates (Table 3, highlighted in grey). For the remaining isolates discrepancies were observed between the two identifications, possibly resulting from limitations of the databases and/or taxonomical constraints - it is well recognized that cyanobacterial taxonomy faces several problems, and is currently under revision [46]. One should point out that 9 of our isolates have less than $97 \%$ similarity to the $16 \mathrm{~S}$ rRNA gene sequences in the database, emphasizing the presence of novel cyanobacterial diversity in Portuguese shore waters (Table 3, dashed boxes).

Phylogenetic analyses were performed to assess the relative positioning of the cyanobacteria isolated in this study. An ML algorithm was applied to a multiple alignment of partial $16 \mathrm{~S}$ rRNA gene sequences $(655 \mathrm{bp}$ ) of all isolates, reference strains, and $C$. aurantiacus $\mathrm{J}-10-\mathrm{fl}$ as the outgroup. The resulting tree revealed 12 consistent clusters $(A-L)$, which were defined as monophyletic groups with bootstrap values equal or higher than $70 \%$ ( Fig. 4). The heterocystous types form a coherent genetic cluster, whereas unicellular and filamentous nonheterocystous forms were intermixed and dispersed throughout the tree, as previously described [10] and [51]. In general, the phylogenetic distribution is congruent with the classification results based on the morphology. Moreover, the species or genus attributed to the isolates in the morphological analysis is in agreement with the species/genus of the reference strains they cluster with. Cluster A includes two isolates identified as Leptolyngbya mycoidea supported by a bootstrap value of $100 \%$. Cluster B comprises one isolate identified as Chroococcopsis sp. and the reference strain Synechocystis sp. PCC 6308. Cluster C includes the Chroococcidiopsis sp. PCC 6712 and an isolate identified as Hyella sp. Cluster D includes 3 isolates belonging to Pleurocapsales, and the reference strainsPleurocapsa sp. PCC 7516, Pleurocapsa sp. PCC 7319, and Myxosarcina sp. PCC 7325, corroborating the close relationship between these two genera. This is in agreement with previous findings, where Myxosarcina sp. PCC 7325 clusters with other members of Pleurocapsa-group: Pleurocapsa sp. PCC 7516 and PCC 7321 [37]. Chroococcidiopsis PCC 7203, Chroococcidiopsis PCC 6712 and Stanieria cyanosphaera PCC 7437, appear distant from all the other baeocyte-forming cyanobacteria, which has been previously reported for Chroococcidiopsis PCC 7203 [37]. Cluster E comprises isolates identified as Leptolyngbya and Phormidium and, although no reference strain is included, it is supported by a bootstrap value of $100 \%$. Cluster $F$ contains three Synechocystis: Synechocystis sp. PCC 6803, and two isolates identified as Synechocystis salina. The reference strain Synechocystis PCC 6308, is unrelated to the above isolates. The scattered distribution of Synechocystis strains has been described previously; Wilmotte and Herdman [51] showed that Synechocystis PCC 6308 did not group with Synechocystis PCC 6803 and Synechocystis PCC 6909. Cluster G includes the genus reference strain Lyngbya sp. PCC 
7419, and one isolate identified as Lyngbya cf. aestuarii (Lyngbya PCC 7419 was originally identified as Lyngbya aestuarii) [5]. Cluster $\mathrm{H}$ contains the heterocystous cyanobacteria, and within it is possible to distinguish two sub-clusters: the Nostoc and Calothrix/Rivularia. Scytonema hofmanni PCC 7101 is not included in this cluster due to a low bootstrap value (48.5) but forms a monophyletic group with the heterocystous types, which is in agreement with previous reports [10], [32] and [51]. This cluster also contains an isolate identified as Plectonema cf. radiosum. As it described earlier, members of this "botanical" genus might beScytonema individuals that do not exhibit heterocysts even in natural samples [35]. Cluster I, constituted mainly of Oscillatoriales morphotypes, contains isolates identified as Leptolyngbya, Pseudophormidium,Pseudanabaena and the reference strain Leptolyngbya PCC 7104. Cluster J contains the Leptolyngbyasp. PCC 7375 and the isolate identified as Pseudanabaena cf. frigida. Cluster $\mathrm{K}$ comprises isolates identified as Pseudanabaena and the marine unicellular Synechococcus PCC 7335. This has been previously observed by Wilmotte and Herdman [51] who reported a close relationship between filamentous cyanobacteria and Synechococcus PCC 7335. Cluster L includes cyanobacteria belonging to Chroococcales and Oscillatoriales. Within this cluster it is possible differentiate a Cyanobium and aSynechococcus sub-cluster. Previously, Herdman et al. [13] reported that Synechococcus WH 8103 was included in the Cyanobium spp. clade, corroborating the data presented here. The same 16S rRNA gene alignment was analyzed by Neighbor-Joining (NJ) ( Fig. S3), and the computed tree supported all the 12 clusters, therefore validating the $\mathrm{ML}$ approach and reinforcing the described phylogenetic analysis. 


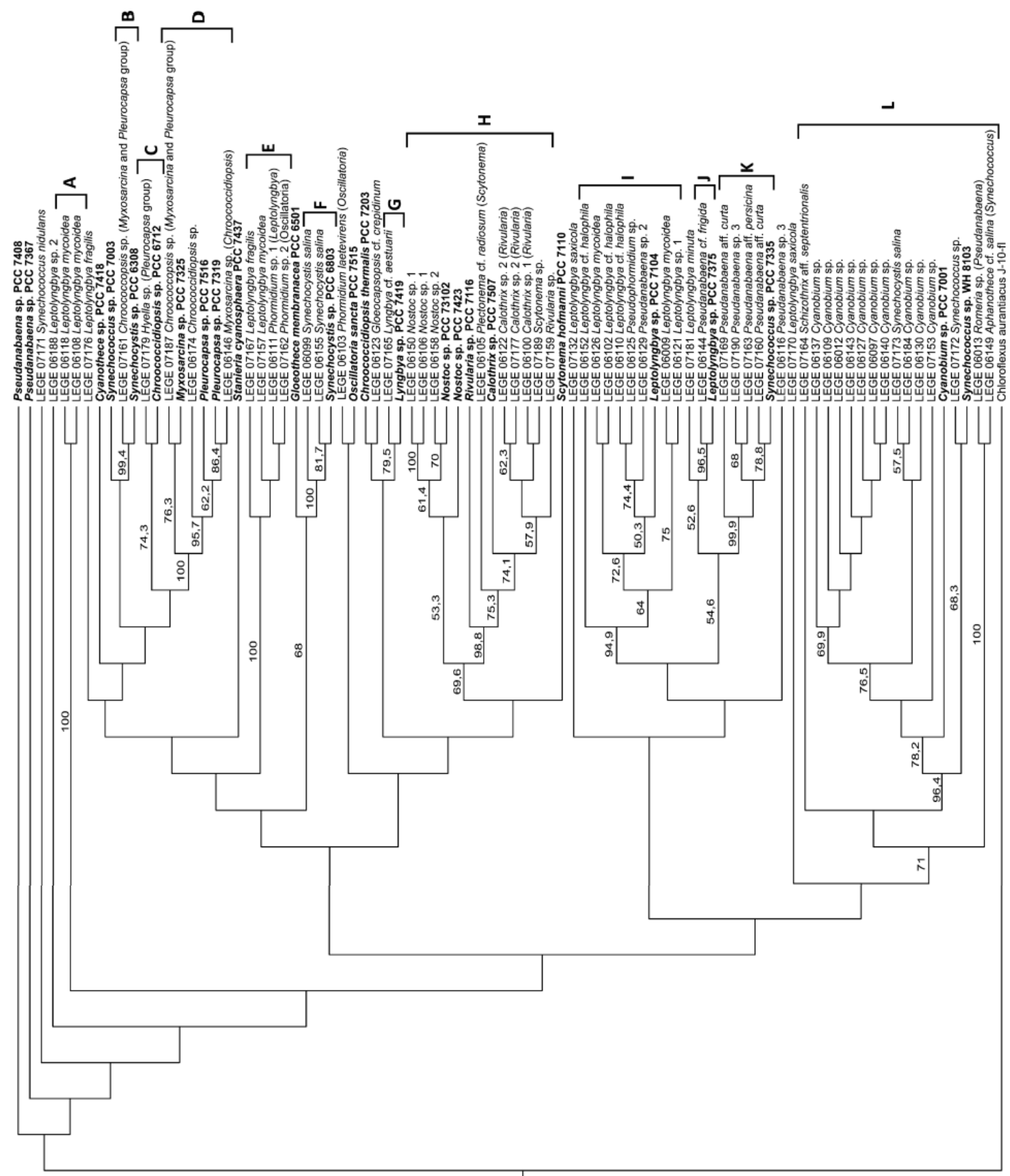

Fig. 4. Maximum-likelihood phylogenetic tree of partial $16 \mathrm{~S}$ rRNA gene sequences from the isolates, reference cyanobacterial strains and the outgroup Chloroflexus aurantiacus $\mathrm{J}-10$-fl. Numbers along branches indicate the percentage of bootstrap support considering 1000 pseudo-replicates: only those equal or higher than $50 \%$ are indicated. Isolates are referred by their culture collection code and morphological identification, whereas reference strains are indicated in bold. The 12 recognized clusters (A-L) are indicated along the tree (see text for details).

It is important to notice that some isolates, identified as the same taxon ( $S$. salina, $L$. mycoidea, Leptolyngbya fragilis), appear in different branches along the tree, indicating that the phylogenetic analyses of small coccoids and some filamentous cyanobacteria offered a higher resolution than the morphological identification.

\section{Screening for putative $\mathrm{N}_{2}$ fixers and toxin producers}

A survey to evaluate the presence of putative $\mathrm{N}_{2}$ fixers and toxin producers was carried out. Isolates were screened for the presence of the genes nifK, nifH, mcyA, mcyE, ndaF and sxt/(see "Materials and methods" section). With the exception of the filamentous heterocystous strains, it is not possible to identify $\mathrm{N}_{2}$-fixing cyanobacteria based on morphology; therefore targeting the 
structural genes encoding the nitrogenase enzymatic complex is a common approach [53] and [54]. In this work, the presence of nifH, nifK and/or heterocysts were taken into account to determine the organism's potential for nitrogen fixation. $33 \%$ of the isolates (20 out of 60 , see Table S1) qualify as potential diazotrophs, suggesting that cyanobacteria may play an important role in $\mathrm{N}_{2}$ fixation in these intertidal zones. Intertidal ecosystems are harsh and often nutrient-limited environments, so the presence of nitrogen fixers is expected and this ability may confer cyanobacteria a competitive advantage [6] and [41]. Indeed, cyanobacteria are the most important $\mathrm{N}_{2}$-fixing organisms in the majority of the marine microbial mats, and high rates of nitrogen fixation have been observed [42]. Concerning the genes encoding proteins involved in toxin production, no amplification was obtained indicating the absence, among the isolates, of cyanobacteria producing the conventional freshwater toxins: microcystin, nodularin and saxitoxin. One should bear in mind that a negative PCR result does not exclude the presence of the gene and, conversely, the presence of the gene does not translate into expression and activity (also valid for the nif genes screening), but the primer pairs used in this study have been proven to work with a wide range of cyanobacterial strains [14], [16] and [17]. Martins et al. [26] demonstrated that extracts of marine Synechocystis and Synechococcus strains isolated from the Portuguese coast were toxic to marine invertebrates possibly implicating the presence of other toxic compounds.

\section{Conclusions}

This study unveils the cultivated diversity of cyanobacteria present in the intertidal zones of the continental Portuguese coast. The isolated cyanobacteria belong to 35 different morphotypes and comprise members of all the cyanobacterial orders/subsections, with the exception of Stigonematales/subsection $\mathrm{V}$. The predominant forms among the isolates were nonheterocystous and were particularly represented by the filamentous Oscillatoriales. The 16S rRNA gene sequences of 9 strains have less than $97 \%$ similarity compared to the sequences in GenBank, revealing unreported cyanobacterial diversity. The phylogenetic distribution, based on the $16 \mathrm{~S}$ rRNA gene, is congruent with the results obtained with the morphology-based classification. As expected, the heterocystous cyanobacteria form a coherent genetic cluster, whereas the unicellular and filamentous nonheterocystous were intermixed. Most of the isolates cluster with reference strains of the same species or genus assigned to the isolates in the morphological identification. One-third of the isolated organisms are putative diazotrophs, suggesting that cyanobacteria may play an important role in $\mathrm{N}_{2}$ fixation along the continental Portuguese coast, as it is common in the marine environment. Additionally, no conventional freshwater toxins genes were detected by PCR screening, indicating a low probability for the occurrence of producers of these cyanotoxins in the analyzed zones. 


\section{References}

[1] R.M.M. Abed, K. Kohls, D. de Beer Effect of salinity changes on the bacterial diversity, photosynthesis and oxygen consumption of cyanobacterial mats from an intertidal flat of the Arabian Gulf Environ. Microbiol., 9 (2007), pp. 1384-1392

[2] R. Araújo, I. Bárbara, M. Tibaldo, E. Berecibar, P.D. Tapia, R. Pereira, R. Santos, I. SousaPinto Checklist of benthic marine algae and cyanobacteria of northern Portugal Bot. Mar., 52 (2009), pp. 24-46

[3] K. Bauer, B. Díez, C. Lugomela, S. Seppala, A.J. Borg, B. Bergman Variability in benthic diazotrophy and cyanobacterial diversity in a tropical intertidal lagoon FEMS Microbiol. Ecol., 63 (2008), pp. 205-221

[4] D.R. Boone, R.W. Castenholz, G.M. Garrity Bergey's Manual of Systematic Bacteriology - The Archaea and the Deeply Branching and Phototrophic Bacteria (2nd ed.), 1Springer, New York, USA (2001), pp. 473-599

[5] R.W. Castenholz Phylum BX. Cyanobacteria. Oxygenic photosynthetic bacteria D.R. Boone, R.W. Castenholz, G.M. Garrity (Eds.), Bergey's Manual of Systematic Bacteriology (2nd ed.), 1Springer, New York, USA (2001), pp. 473-599

[6] B. Díez, K. Bauer, B. Bergman Epilithic cyanobacterial communities of a marine tropical beach rock (Heron Island, Great Barrier Reef): diversity and diazotrophy Appl. Environ. Microbiol., 73 (2007), pp. 3656-3668

[7] Drummond, A.J., Ashton, B., Buxton, S., Cheung, M., Cooper, A., Duran, C., Field, M., Heled, J., Kearse, M., Markowitz, S., Moir, R., Stones-Havas, S., Sturrock, S., Thierer, T., Wilson, A. (2011) Geneious v5.4, Available from http://www.geneious.com/.

[8] J. Felsenstein Evolutionary trees from DNA sequences: a maximum likelihood approach J. Mol. Evol., 17 (1981), pp. 368-376

[9] B. Frazão, R. Martins, V. Vasconcelos Are known cyanotoxins involved in the toxicity of Picoplanktonic and filamentous North Atlantic marine cyanobacteria? Mar. Drugs, 8 (2010), pp. 1908-1919

[10] S.F. Giovannoni, S. Turner, G. Olsen, S. Barns, D.J. Lane, N.R. Pace Evolutionary relationships among cyanobacteria and green chloroplasts J. Bacteriol., 170 (1988), pp. 3584-3592 [11] M.F. Gugger, L. Hoffmann Polyphyly of true branching cyanobacteria (Stigonematales) Int. J. Syst. Evol. Microbiol., 54 (2004), pp. 349-357

[12] S. Guindon, O. Gascuel A simple, fast, and accurate algorithm to estimate large phylogenies by maximum likelihood Syst. Biol., 52 (2003), pp. 696-704

[13] M. Herdman, R.W. Castenholz, I. Iteman, J.B. Waterbury, R. Rippka Subsection I (formerly Chroococcales Wettstein 1924, emend. Rippka, Deruelles, Waterbury, Herdman and Stanier 1979) D.R. Boone, R.W. Castenholz (Eds.), Bergey's Manual of Systematic Bacteriology (2nd ed.), 1Springer, New York (2001), pp. 493-514

[14] M. Hisbergues, G. Christiansen, L. Rouhiainen, K. Sivonen, T. Börner PCR-based identification of mycrocystin-producing genotypes of different cyanobacterial genera Arch. Microbiol., 180 (2003), pp. 402-410 
[15] L. Hoffman, R.W. Castenholz Subsection V (formerly Stigonematales Geitler 1925) D.R. Boone, R.W. Castenholz (Eds.), Bergey's Manual of Systematic Bacteriology (2nd ed.), 1Springer, New York (2001), pp. 589-599

[16] A.-D. Jungblut, B.A. Neilan Molecular identification and evolution of the cyclic peptide hepatotoxins, microcystin and nodularin, synthetase genes in three orders of cyanobacteria Arch. Microbiol., 185 (2006), pp. 107-114

[17] R. Kellmann, T.K. Michali, B.A. Neilan Identification of a saxitoxin biosynthesis gene with a history of frequent horizontal gene transfer J. Mol. Evol., 67 (2008), pp. 526-538

[18] A.H. Knoll Cyanobacteria and earth history A. Herrero, E. Flores (Eds.), Cyanobacteria: Molecular Biology, Genomics and Evolution, Caister Academic Press, Norfolk, UK (2008), pp. 1-19 [19] J. Komárek, K. Anagnostidis Modern approach to the classification system of Cyanophytes.

4. Nostocales Arch. Hydrobiol. Suppl., 82 (1989), pp. 247-345

[20] J. Komárek, K. Anagnostidis Cyanoprokaryota. 1. Teil: Chroococcales H. Ettl, G. Gartner, H. Heynig, D. Mollenhauer (Eds.), Süsswasserflora von Mitteleuropa, vol. 19/1Gustav Fischer, Stuttgart (1998), p. 548

[21] J. Komárek, K. Anagnostidis Cyanoprokaryota 2 Teil/2nd part: Oscillatoriales B. Büdel, L. Krienitz, G. Gärtner, M. Schagerl (Eds.), Süsswasserflora von Mitteleuropa, vol. 19/2Elsevier/Spektrum, Heidelberg (2005), p. 759

[22] J. Kotai Instructions for Preparation of Modified Nutrient Solution Z8 for Algae, Publication

B-11769 Norwegian Institute for Water Research, Blindern, Oslo (1972)

[23] M. Kottek, J. Grieser, C. Beck, B. Rudolf, F. Rubel World map of the Köppen-Geiger climate classification updated Meteorol. Z., 15 (2006), pp. 259-263

[24] M.A. Larkin, G. Blackshields, N.P. Brown, R. Chenna, P.A. McGettigan, H. McWilliam, F. Valentin, I.M. Wallace, A. Wilm, R. Lopez, J.D. Thompson, T.J. Gibson, D.G. Higgins Clustal W and Clustal X version 2.0 Bioinformatics, 23 (2007), pp. 2947-2948

[25] F.P. Lima, N. Queiroz, P.A. Ribeiro, S.J. Hawkins, A.M. Santos Recent changes in the distribution of a marine gastropod, Patella rustica Linnaeus, 1758, and their relationship to unusual climatic events J. Biogeogr., 33 (2006), pp. 812-822

[26] R. Martins, N. Fernandez, R. Beiras, V. Vasconcelos Toxicity assessment of crude and partially purified extracts of marine Synechocystis and Synechococcus cyanobacterial strains in marine invertebrates Toxicon, 50 (2007), pp. 791-799

[27] M. Mühling, J. Woolven-Allen, J.C. Murrell, I. Joint Improved group-specific PCR primers for denaturing gradient gel electrophoresis analysis of the genetic diversity of complex microbial communities ISME J., 2 (2008), pp. 379-392

[28] U. Nübel, F. Garcia-Pichel, G. Muyzer PCR primers to amplify 16S rRNA genes from cyanobacteria Appl. Environ. Microbiol., 63 (1997), pp. 3327-3332

[29]E.O. Omoregie, L.L. Crumbliss, B.M. Bebout, J.P. Zehr Comparison of diazotroph community structure in Lyngbya sp. and Microcoleus chthonoplastesdominated microbial mats from Guerrero Negro, Baja, Mexico FEMS Microbiol. Ecol., 47 (2004), pp. 305-318

[30] M.T. Pontes, R. Aguiar, H.O. Pires A nearshore wave energy atlas for Portugal J. Offshore Mech. Arct. Eng., 127 (2005), pp. 249-255 
[31] M. Potts Mechanisms of desiccation tolerance in cyanobacteria Eur. J. Phycol., 34 (1999), pp. 319-328

[32] P. Rajaniemi, P. Hrouzek, K. Kastovska, R. Willame, A. Rantala, L. Hoffmann, J. Komárek, K. Sivonen Phylogenetic and morphological evaluation of the genera Anabaena, Aphanizomenon, Trichormus and Nostoc (Nostocales, Cyanobacteria) Int. J. Syst. Evol. Microbiol., 55 (2005), pp. 11-26

[33] V. Ramos, R. Seabra, Â. Brito, A. Santos, C.L. Santos, M. Lopo, P. Moradas-Ferreira, V.M. Vasconcelos, $P$. Tamagnini Characterization of an intertidal cyanobacterium that constitutes a separate clade together with thermophilic strains Eur. J. Phycol., 45 (2010), pp. 394-403

[34] R. Rippka Isolation and purification of cyanobacteria L. Packer, A.N. Glazer (Eds.), Methods in Enzymology, vol. 167Academic Press, San Diego (1988), pp. 3-27

[35] R. Rippka, R.W. Castenholz, M. Herdman Subsection IV (formerly Nostocales Castenholz 1989b sensu Rippka, Deruelles, Waterbury, Herdman and Stanier 1979) D.R. Boone, R.W. Castenholz (Eds.), Bergey's Manual of Systematic Bacteriology (2nd ed.), vol. 1Springer, New York (2001), pp. 562-589

[36] R. Rippka, J. Deruelles, J.B. Waterbury, M. Herdman, R.Y. Stanier Generic assignments, strain histories and properties of pure cultures of cyanobacteria J. Gen. Microbiol., 111 (1979), pp. $1-61$

[37] R. Rippka, J.B. Waterbury, M. Herdman, R.W. Castenholz Subsection II (formerly Pleurocapsales Geitler 1925, emend. Waterbury and Stanier 1978) D.R. Boone, R.W. Castenholz (Eds.), Bergey's Manual of Systematic Bacteriology (2nd ed.), vol. 1Springer, New York (2001), pp. 514539

[38] J. Sambrook, D.W. Russell Molecular Cloning: A Laboratory Manual (3rd ed.)Cold Spring Harbor Laboratory Press, New York, USA (2001)

[39] R. Seabra, A. Santos, S. Pereira, P. Moradas-Ferreira, P. Tamagnini Immunolocalization of the uptake hydrogenase in the marine cyanobacterium Lyngbya majusculaCCAP 1446/4 and two Nostoc strains FEMS Microbiol. Lett., 292 (2009), pp. 57-62

[40] R. Seabra, D.S. Wethey, A.M. Santos, F.P. Lima Side matters: microhabitat influence on intertidal heat stress over a large geographical scale J. Exp. Mar. Biol. Ecol., 400 (2011), pp. 200208

[41] I. Severin, S.G. Acinas, L.J. Stal Diversity of nitrogen-fixing bacteria in cyanobacterial mats FEMS Microbiol. Ecol., 73 (2010), pp. 514-525

[42] L.J. Stal Cyanobacterial mats and stromatolites B.A. Whitton, M. Potts (Eds.), The Ecology of Cyanobacteria: Their Diversity in Time and Space, Kluwer Academic, Dordrecht, The Netherlands (2000), pp. $61-120$

[43] L.J. Stal, W.E. Krumbein Isolation and characterization of cyanobateria from a marine microbial mat Bot. Mar., 28 (1985), pp. 351-365

[44] R.Y. Stanier, R. Kunisawa, M. Mandel, G. Cohen-Bazire Purification and properties of unicellular blue-green algae (order Chroococcales) Bacteriol. Rev., 35 (1971), pp. 171-205 
[45] P. Tamagnini, O. Troshina, F. Oxelfelt, R. Salema, P. Lindblad Hydrogenases in Nostoc sp. strain PCC 73102, a strain lacking a bidirectional enzyme Appl. Environ. Microbiol., 63 (1997), pp. 1801-1807

[46] A. Taton, S. Grubisic, D. Ertz, D.A. Hodgson, R. Piccardi, N. Biondi, M.R. Tredici, M. Mainini, D. Losi, F. Marinelli, A. Wilmotte Polyphasic study of Antarctic cyanobacterial strains J. Phycol., 42 (2006), pp. 1257-1270

[47] J.B. Waterbury, R.Y. Stanier Patterns of growth and development in pleurocapsalean cyanobacteria Microbiol. Mol. Biol. Rev., 42 (1978), pp. 2-44

[48] W.G. Weisburg, S.M. Barns, D.A. Pelletier, D.J. Lane 16S ribossomal DNA amplification for phylogenetic study J. Bacteriol., 173 (1991), pp. 697-703

[49] B.A. Whitton, M. Potts Introduction to the cyanobacteria B.A. Whitton, M. Potts (Eds.), The Ecology of Cyanobacteria: Their Diversity in Time and Space, Kluwer Academic, Dordrecht, The Netherlands (2000), pp. 1-11

[50] C. Wiegand, S. Pflugmacher Ecotoxicological effects of selected cyanobacterial secondary metabolites a short review Toxicol. Appl. Pharmacol., 203 (2005), pp. 201-218

[51] A. Wilmotte, M. Herdman Phylogenetic relationships among the cyanobacteria based on 16 S rRNA sequences D.R. Boone, R.W. Castenholz (Eds.), Bergey's Manual of Systematic Bacteriology (2nd ed.), 1Springer, New York (2001), pp. 487-493

[52] A. Wilmotte, A.G. van der Auwera, R. de Watcher Structure of the 16S ribosomal RNA of the thermophilic cyanobacterium Chlorogloeopsis HTF ('Mastigocladus laminosus HTF') strain PCC 7518, and phylogenetic analysis FEBS Lett., 317 (1993), pp. 96-100

[53] J.P. Zehr Nitrogen fixation by marine cyanobacteria Trends Microbiol., 19 (2011), pp. 162-173

[54] J.P. Zehr, M.T. Mellon, S. Zani New nitrogen fixing microorganisms detected in oligotrophic oceans by the amplification of nitrogenase (nifH) genes Appl. Environ. Microbiol., 64 (1998), pp. 